\title{
SIKAP MAHASISWA JURUSAN PENDIDIKAN LUAR BIASA \\ FAKULTAS ILMU PENDIDIKAN UNIVERSITAS NEGERI JAKARTA TERHADAP PENINGKATAN KETERAMPILAN SOSIALISASI ANAK TUNA GRAHITA MELALUI PENDIDIKAN INKLUSIF
}

\section{Siti Nuraini}

\begin{abstract}
The purpose of this research is to discover the attitude of the students of special education program at School of Education, State University of Jakarta towards the development of social skills of the students with intellectual skills through inclusive education. This research conducted in the academic year of 2006/2007 used closed questionnaire with Likert Scale, for the sample 30 students were selected purposively. The findings show that the students' attitude in ranged between positive and negative.
\end{abstract}

Keywords: intellectual disabilities, socialization, inclusive education.

\section{PENDAHULUAN}

Pendidikan inklusif muncul dengan memperhatikan hak asasi manusia di mana pada sekitar tahun 1980an fakta menunjukkan banyak anak menjadi korban label dan pemisahan. Beberapa siswa di kelas khusus ternyata juga mengalami kesulitan baik dalam bidang akademik maupun dalam kehidupan sosial terutama dengan mereka yang "normal". Nampaknya kegagalan yang dialami dalam pendidikan luar biasa atau pendidikan khusus adalah terkadang menempatkan siswa berkebutuhan khusus yang tidak sesuai dengan kondisi mereka.

Pendidikan inklusif telah dilaksanakan di beberapa negara seperti Australia dan di Selandia Baru. Di Indonesia istilah inklusif juga kian populer. Istilah ini telah berulang kali masuk ke DPR, dan Direktorat Pendidikan Luar Biasa (PLB) mulai tahun 2001 mengembangkan pendidikan inklusif menjadi salah satu dari program mereka. Demikian pula dengan Pusat Penelitian Balitbangdiknas juga telah mengadakan uji coba pendidikan inklusif di daerah Wonosari, Gunung Kidul, Yogyakarta.

Pendidikan inklusif berarti memergerkan atau menggabungkan antara pendidikan segregatif dengan pendidikan reguler menjadi suatu pendidikan yang beragam (a unified education). Salah satu kelebihan dengan dilaksanakannya pendidikan inklusif adalah meningkatkan derajat dan persamaan hak semua anak dengan tidak terkecuali. Hal ini didukung oleh deklarasi dunia yang terkenal dengan deklarasi Salamanca namun ternyata pelaksanaan pendidikan inklusif tidaklah mudah.

Pro dan kontra argumentasi dalam melaksanakan pendidikan inklusif harus dikaji secara mendalam, mengingat yang akan diinklusifkan adalah anak-anak yang memerlukan layanan pendidikan khusus dengan berbagai karakteristik. Berbagai pendapat dan sikap masyarakat baik dari kalangan awam dan akademisipun beragam

Ketidakmampuan intelektual atau tunagrahita adalah salah satu kajian dari pendidikan khusus. Anak-anak yang memiliki ketidakmampuan dalam intelektual perlu diberi kesempatan untuk mengenyam pendidikan di sekolah reguler. Penelitian sebelumnya tentang persepsi siswa reguler terhadap siswa dengan ketidakmampuan intelektual ternyata positif. Siswa reguler tersebut menyambut baik apabila belajar bersama di kelas dengan siswa tunagrahita.

Akan tetapi, penelitian lain tentang persepsi guru dan kepala Sekolah Luar Biasa (SLB) dan sekolah reguler menunjukkan keberatannya apabila siswa dengan ketidakmampuan intelektual belajar di sekolah reguler dengan berbagai alasan.

Untuk melengkapi gambaran tentang penerimaan terhadap siswa dengan ketidakmampuan intelektual atau lebih terkenal dengan istilah tunagrahita di sekolah reguler maka penelitian ini akan memfokuskan pada sikap mahasiswa Jurusan PLB FIP UNJ terhadap perkembangan keterampilan sosial anak tunagrahita melalui pendidikan inklusif.

Perspektif Ilmu Pendidikan - Vol. 17 Th. IX April 2008 


\section{KAJIAN TEORETIS}

\section{Deskripsi Sikap}

Menurut Morgan, dkk. (1986), sikap adalah ekspresi individual yang merupakan evaluasi dari suatu sikap dari objek tertentu. Evaluasi terhadap objek itu diekspresikan menjadi sesuatu yang berhubungan dengan suka, tidak suka, setuju, tidak setuju, positif atau negatif, dan nikmat atau tidak nikmat.

Wortmand, dkk. (1985) menyatakan bahwa sikap adalah suatu perasaan dekat atau tidak dekat atau pemahaman dengan atau terhadap sekelompok orang tertentu, objek tertentu, ide-ide, atau situasi. Dengan demikian, sikap adalah suatu tentang suka atau tidak suka dari perasaan seseorang. Wortmand, dkk. (1985) mengutip Insko dan Scholer (1976), dan Papalia dan Wendkos (1985) menyatakan bahwa sikap adalah suatu konsep yang terdiri dari tiga komponen dasar, yaitu (1) kognisi atau kepercayaan tentang seseorang, ide-ide, situasi dan sesuatu; (2) reaksi emosi menuju suatu stimulus; dan (3) kecenderungan untuk bertindak.

Dari batasan-batasan di atas terdapat suatu persamaan bahwa sikap adalah sesuatu yang berhubungan dengan suka atau tidak suka, setuju atau tidak terhadap sesuatu tertentu seperti orang, situasi, dan ide. Kesemuanya berdasarkan kepada hasil evaluasi terhadap sesuatu. Lebih dalam lagi, Wortmand (1985) mengutip Insko dan Scholer (1976) serta Papalia dan Wendkos (1985) menyatakan sikap terdiri dari kognisi, reaksi emosi, dan kecenderungan untuk bertindak. Jadi, dapat disimpulkan bahwa sikap adalah suatu kecenderungan untuk bertindak hasil dari evaluasi terhadap suatu objek yang merupakan hasil dari kognisi dan reaksi emosi yang dinyatakan dalam bentuk suka atau tidak suka, setuju atau tidak setuju, positif atau negatif, dan nikmat atau tidak nikmat.

Sikap menurut Papalia dan Wendkos (1985) adalah dipelajari. Hal ini sesuai dengan teori belajar, yaitu belajar sikap sama seperti belajar yang lain. Ketika belajar suatu informasi yang baru maka kita belajar tentang berbagai perasaan, pikiran, dan reaksireaksi yang berhubungan dengan hal yang dipelajari.

Terbentuknya atau berubahnya sikap adalah akibat dari hasil hubungan interpersonal terhadap sesuatu pada suatu periode tertentu. Wortmand, dkk. (1985) menegaskan bahwa sikap adalah dipelajari, sikap juga berlangsung untuk waktu yang lama, dan sikap mendorong kita untuk beraksi membantu untuk membentuk langsung tingkah laku terhadap sesuatu. Prejudis adalah suatu bentuk sikap negatif terhadap sesuatu karena tidak memahami sesuatu.
Jadi, dapat disimpulkan bahwa sikap terbentuk karena dipelajari atau karena hasil interaksi terhadap sesuatu. Hasil interaksi membentuk suatu kecenderungan untuk bertingkah laku. Dari beberapa pendapat dapat dinyatakan pula bahwa sikap itu menjadi sesuatu yang cenderung permanen. Dengan demikian, untuk mengubah suatu sikap tertentu diperlukan waktu yang lama. Hal ini sesuai dengan ketika suatu sikap pertama terbentuk, diperlukan waktu yang lama sehingga untuk mengubah menjadi suatu sikap yang berbeda maka diperlukan waktu yang lama pula. Apalagi kalau sikap itu sudah bersifat permanen.

Thurstone (1931) seperti yang dikutip oleh Muller (1986:4) menyatakan bahwa sikap adalah menyukai atau menolak suatu objek psikologis. Ini berarti bahwa sikap memiliki objek psikologis. Hal ini diperkuat oleh pendapat dari Azwar (1995) yang mengutip pendapat dari Breckler, dkk bahwa sikap adalah suatu reaksi terhadap objek kombinasi dari afektif, konasi, dan kognitif.

Selanjutnya menurut Azwar (1995) yang dimaksud dengan kognitif adalah berisi kepercayaan dari seseorang tentang apa yang berlaku atau benar bagi objek sikap. Namun selanjutnya, ia menyatakan bahwa kepercayaan itu kadang kurang akurat akibat dari kurang atau tidak adanya informasi yang benar tentang objek yang dihadapi. Kognisi menurut Chaplin (1993) dinyatakan sebagai suatu konsep umum yang berkenaan dengan pengenalan seperti mengamati, menduga dan menilai, serta berpikir.

Masalah emosional yang subjektif dari seseorang terhadap suatu objek dinamakan dengan komponen afeksi (Azwar, 1995). Pandangan dari Rosenberg yang dikutip oleh Azwar (1995) menyatakan hal yang sama tentang afektif, yaitu suatu perasaan positif atau negatif dari seseorang terhadap suatu objek.

Komponen lain dari sikap adalah komponen konasi atau perilaku yang berhubungan dengan kecenderungan dalam diri seseorang untuk berperilaku terhadap objek yang dihadapinya (Azwar, 1995). Ini sejalan dengan pendapat dari Chaplin (1993) bahwa konasi adalah salah satu aspek kepribadian yang ditandai dengan tingkah laku yang bertujuan untuk berbuat.

Sikap dinyatakan sesuatu yang berhubungan dengan kecenderungan untuk bertindak. Pernyataan dari sikap adalah setuju atau tidak setuju, suka atau tidak suka, pro atau anti, dan nikmat atau tidak nikmat.

Sebagai individu yang belajar di perguruan tinggi maka perkembangan mahasiswa atau usia 18 
tahun ke atas adalah pada tingkatan formal operasional menurut Piaget. Pada tahapan ini individu mampu untuk menyatakan suatu alasan tentang outcomes, dapat mempertimbangkan hal-hal abstrak seperti agama, moral, dan alternatif gaya hidup.

Sebagai mahasiswa Jurusan PLB yang mempelajari tentang anak dan individu berkebutuhan khusus, seharusnya memiliki suatu sikap yang dapat care dan sharing dengan anak berkebutuhan khusus termasuk dengan anak tunagrahita. Hal ini dikarenakan mahasiswa Jurusan PLB lebih mengetahui tentang karakteristik dan layanan kebutuhan serta kekurangan dari anak dan individu berkebutuhan khusus.

Sikap dinyatakan dipelajari dan bersifat permanen. Sikap mahasiswa Jurusan PLB terbentuk dari rumah, teman, masyarakat, dan Jurusan PLB. Faktor-faktor tersebut sangat mempengaruhi sikap mahasiswa Jurusan PLB terhadap, antara lain sesuatu, seseorang, atau ide-ide.

Dari beberapa pendapat di atas dinyatakan bahwa sikap memiliki tiga komponen, yaitu kognitif, afektif, dan konasi. Hal ini berarti apabila seseorang akan melihat sikap dari seseorang atau kelompok maka haruslah melihat dari ketiga komponen tersebut. Kognitif berhubungan dengan respon perseptual, pernyataan lisan tentang keyakinan; afektif berhubungan dengan respon syaraf simpatetik dan pernyataan lisan tentang efek; dan konasi berhubungan dengan pernyataan lisan tentang perilaku.

\section{Deskripsi Sosialisasi}

Sosialisasi merupakan suatu proses yang terus berlangsung di mana anak secara natural bererotik dan berinsting agresif yang secara perlahan-lahan dibawa ke bawah kontrol dari superego. Selanjutnya sosialisasi dipengaruhi oleh kepribadian pola asuh orang tua, keluarga, budaya, dan nilai-nilai yang ada di masyarakat. Demikian pula dengan Henslin (1999) menyatakan bahwa masyarakat dan kelompokkelompok sebagai agen-agen dari sosialisasi mempengaruhi konsep diri, emosi, sikap, dan tingkah laku dari seseorang.

Menurut Gursec (1985) tujuan utama dari sosialisasi adalah untuk memberi dampak kepada anak-anak untuk berubah dari berpusat pada dirinya kepada minat ke orang lain. Selama bersosialisasi manusia belajar bahasa dari budaya, belajar berbagai peranan pekerjaan di mana manusia sering mengadopsi norma-norma budaya ketika belajar bersosial.

Kalangan sosiologis membedakan enam macam sosialisasi, di antaranya (1) sosialisasi keterbalikan (reverse socialization), (2) perkembangan sosialisasi (development socialization), (3) sosialisasi utama (primary socialization), (4) sosialisasi kedua (secondary socialization) (5) sosialisasi antisipasi (anticipatory socialization), dan (6) mensosialisasikan kembali (resocialization). Reverse socialization adalah suatu penyimpangan dari tingkah laku yang diharapkan biasanya dilakukan oleh anak-anak muda. Development socialization adalah proses belajar dalam lembaga sosial untuk mengembangkan keterampilan sosial. Primary socialization adalah suatu proses di mana manusia belajar tentang sikap, nilai-nilai, dan tingkah laku yang sesuai kepada manusia lain serta masyarakat dari suatu budaya tertentu. Secondary socialization adalah suatu proses belajar tentang tingkah laku yang baik sebagai anggota dari suatu kelompok kecil dalam suatu kelompok masyarakat besar. Anticipatory socialization merujuk pada suatu proses sosialisasi di mana seseorang berlatih untuk berbagai posisi di masa depan, berbagai pekerjaan, dan berbagai hubungan sosial. Resocialization adalah suatu proses membuang suatu pola tingkah laku dan menerima suatu tingkah laku baru sebagai suatu transisi dalam kehidupan seseorang.

Berdasarkan keenam macam sosialisasi maka dapat dinyatakan bahwa kebiasaan, ide-ide, sikap, dan nilai-nilai dikembangkan melalui proses sosialisasi. Selain itu, dapat tergambarkan bahwa sosialisasi terjadi apabila seseorang diberitahu apa yang harus dikerjakan dan bagaimana bertingkah laku. Pada umumnya sosialisasi dipelajari secara tidak langsung ketika bersama dengan orang lain. Dengan demikian, dapat disimpulkan bahwa sosialisasi adalah suatu proses belajar tentang suatu pengetahuan, pemahaman, sikap, dan tingkah laku yang ber-langsung secara terus menerus. Proses sosialisasi yang terbaik adalah pada usia satu sampai sepuluh tahun.

Menurut teori intelegensi sosial terdapat lima kategori dasar keterampilan sosial, yaitu (1) kesadaran akan situasi (social or situational awareness), (2) keberadaan (presence), (3) keaslian (authenticity), (4) kejelasan (clarity), dan (5) empati (empathy). Sosialisasi dinyatakan dengan suatu proses belajar tentang suatu pengetahuan, pemahaman, sikap, dan tingkah laku yang berlangsung secara terus menerus. Proses sosialisasi yang terbaik adalah pada usia satu sampai sepuluh tahun.

Keterampilan sosialisasi adalah suatu kemampuan khusus yang merupakan suatu proses belajar tentang pengetahuan, pemahaman, sikap, dan bertingkah laku dalam berinteraksi dan berhubungan 
dengan orang lain yang melibatkan kesadaran akan situasional, keberadaan seseorang dalam suatu lingkup tertentu, keaslian seseorang dalam bertingkah laku, kejelasan seseorang dalam memberikan penjelasan terhadap orang lain, dan perasaan empati dalam kaitannya dengan membangun suatu hubungan dengan orang lain.

Keterampilan sosialisasi terdiri dari enam macam, yaitu keterampilan sosialisasi keterbalikan atau memiliki suatu tingkah laku yang berbeda dengan masyarakat, keterampilan sosialisasi yang dibelajarkan pada lembaga sosial, keterampilan sosialisasi yang sesuai dengan nilai-nilai masyarakat tertentu, keterampilan sosialisasi dalam bertingkah laku yang sesuai dengan masyarakat kecil yang merupakan bagian dari masyarakat besar, keterampilan sosialisasi dalam mengantisipasi masa depan seperti pada bidang pekerjaan dan posisi, serta keterampilan sosialisasi dalam membuang tingkah laku yang telah dimiliki untuk memiliki suatu tingkah laku baru.

\section{Deskripsi Tunagrahita}

Berbagai istilah telah digunakan untuk menjelaskan tentang anak dengan ketidakmampuan intelektual. Di masa lalu tidak ada perbedaan antara mereka yang tidak mampu dalam intelektual dengan penyakit mental, perbedaan dimulai pada pertengahan abad (the American Association on Mental Defficiency, di kutip dari Grossman, 1983).

Pada saat ini batasan untuk tunagrahita yang banyak digunakan adalah batasan dari the American Association On Mental Retardation (AAMR) yang dulu dikenal dengan istilah $A A M D$ yang nampaknya batasan ini ini lebih luas, yaitu “... mental retardation refers to substantial limitations in present functioning. It is characterised by significantly subaverage intellectual functioning, existing concurrently with related limitations in two or more of the following applicable adaptive skills areas: communication, self-care, home living, social skills, community use, self-direction, health and safety, functional academics, leisure and work. Mental retardation manifests before age 18" (Ashman, 1994:438).

Dari batasan ini terlihat bahwa untuk menunjukkan bahwa seseorang itu memiliki ketidakmampuan intelektual harus ada tiga hal yang penting, yaitu fungsi intelektual di bawah rata-rata, keterbatasan dalam keterampilan beradaptasi, dan manifestasinya sebelum usia 18 tahun atau pada periode perkembangan.

Weiten (1989) mengklasifikasikan ketidakmampuan intelektual dalam empat level, yaitu ringan, sedang, berat, dan sangat berat. Menurutnya level $I Q$ dari yang ringan adalah sekitar 50-70 dan setara dengan anak-anak berusia 8-12 tahun. Level IQ sedang, yaitu 35-50 di mana setara dengan anak-anak usia 6-8 tahun. Level IQ berat, yaitu 20-35 dan setara dengan anak-anak usia 3-6 tahun dan sangat berat ber $I Q$ di bawah 20 serta setara dengan anak-anak usia 0-3 tahun.

Ashman (1994) membagi klasifikasi ketidakmampuan intelektual dalam level ringan ber IQ 52-68 pada skala Binet dan 55-69 pada skala Wechsler, level sedang ber $I Q$ 36-51 pada skala Binet dan 40-54 pada skala Wechsler, level berat ber IQ 20-35 pada skala Binet dan 25-39 pada skala Wechsler, dan level sangat berat ber $I Q$ kurang dari 19 pada skala Binet dan di bawah 24 pada skala Wechsler. Namun, tes $I Q$ menurut Ashman (1994) hanya menyatakan sedikit tentang aktual $I Q$ dan bagaimana individual menghadapi berbagai permasalahan sehari-hari. Selanjutnya Anastasi dan Urbina (1997) menyatakan bahwa tes intelegensi digunakan untuk membantu dalam memahami dan tidak harus digunakan untuk melabelkan individu.

Tunagrahita adalah istilah yang digunakan di Indonesia untuk merujuk pada ketidakmampuan intelektual. Di Indonesia batasan dan klasifikasi untuk menunjukkan seseorang tunagrahita hanya melalui tes intelegensi sedangkan tes adaptasi belum banyak digunakan. Pernyataan untuk menunjukkan tunagrahita tergantung pada skala tes yang digunakan.

Pada individu dengan tunagrahita beberapa memiliki hambatan yang beragam. Beberapa hambatan yang dialami oleh mereka yang memiliki ketidakmampuan intelektual, antara lain terbatasnya keterampilan berbahasa sehingga mereka mengalami kesulitan dalam menambah atau menghilangkan bagian dari kata yang dapat mempengaruhi pengertian dari kata tersebut (Hallahan dan Kauffman, 1986) dan hambatan memori yang nantinya berhubungan dengan pemahaman tugas-tugas atau instruksi (Drew, Logan dan Hardman, 1990). Selain itu, beberapa dari mereka mengalami gangguan tingkah laku seperti memukulkan kepala mereka ke dinding dan menggetarkan badan ditemukan oleh Cartwright, Cartwright dan Ward (1989) sehingga anak-anak ini mengalami kesulitan dalam berpartisipasi dengan baik di masyarakat. Dapat disimpulkan bahwa anak tunagrahita memiliki beberapa hambatan lain yaitu dalam bidang bahasa, fisik, gangguan emosi, dan tingkah laku. Kondisi seperti ini harus dijadikan sebagai bahan pertimbangan dalam pelaksanaan pendidikan inklusif.

Menurut Drew, dkk. (1990), mereka yang tergolong ringan dapat bersekolah di sekolah umum 
dan mendapatkan keuntungan dari sistem tersebut seperti kurikulum yang sama dengan modifikasi berdasarkan kebutuhan mereka. Hal ini ditopang oleh deklarasi dunia tentang pendidikan untuk semua, yaitu:

1. every person - child, youth and adult, shall be able to benefit from educational opportunities designed to meet their basic learning needs, and

2. the learning needs of the disabled demand special attention. Steps need to be taken to provide equal access to education to every category of disabled person as an integral part of the education system (Mitchell, 1994:3).

Selanjutnya dalam dokumen Salamanca (1994) seperti yang dikutip oleh Mitchel (1994:viii) dinyatakan bahwa:

1. every child has a fundamental right to education, and must be given the opportunity to achieve and manintain an acceptable level of learning,

2. every child has unique characteristics, interests, abilities and learning needs. Education systems should be designed and educational programmes implemented to take into account the wide diversity of these characteristics and needs, and

3. those with special educational needs must have access to reguler schools which should accomodate them within a childcentred pedagogy capable of meeting these needs.

Hal ini terlihat bahwa semua anak termasuk anak-anak dengan kebutuhan khusus berhak mempunyai akses mendapatkan pendidikan pada lembaga-lembaga pendidikan reguler.

Pendidikan inklusif yang menjadi suatu isu adalah "... the merger of special and regular education into a unified education system" (Andrew, dkk., 1993:5), dengan kata lain penyatuan pendidikan khusus dan pendidikan reguler menjadi suatu sistem pendidikan yang beragam. Namun kenyataannya sampai saat ini pendidikan inklusif masih diperdebatkan karena membangun atmosfir inklusif memerlukan beberapa faktor pendukung seperti gambar berikut ini

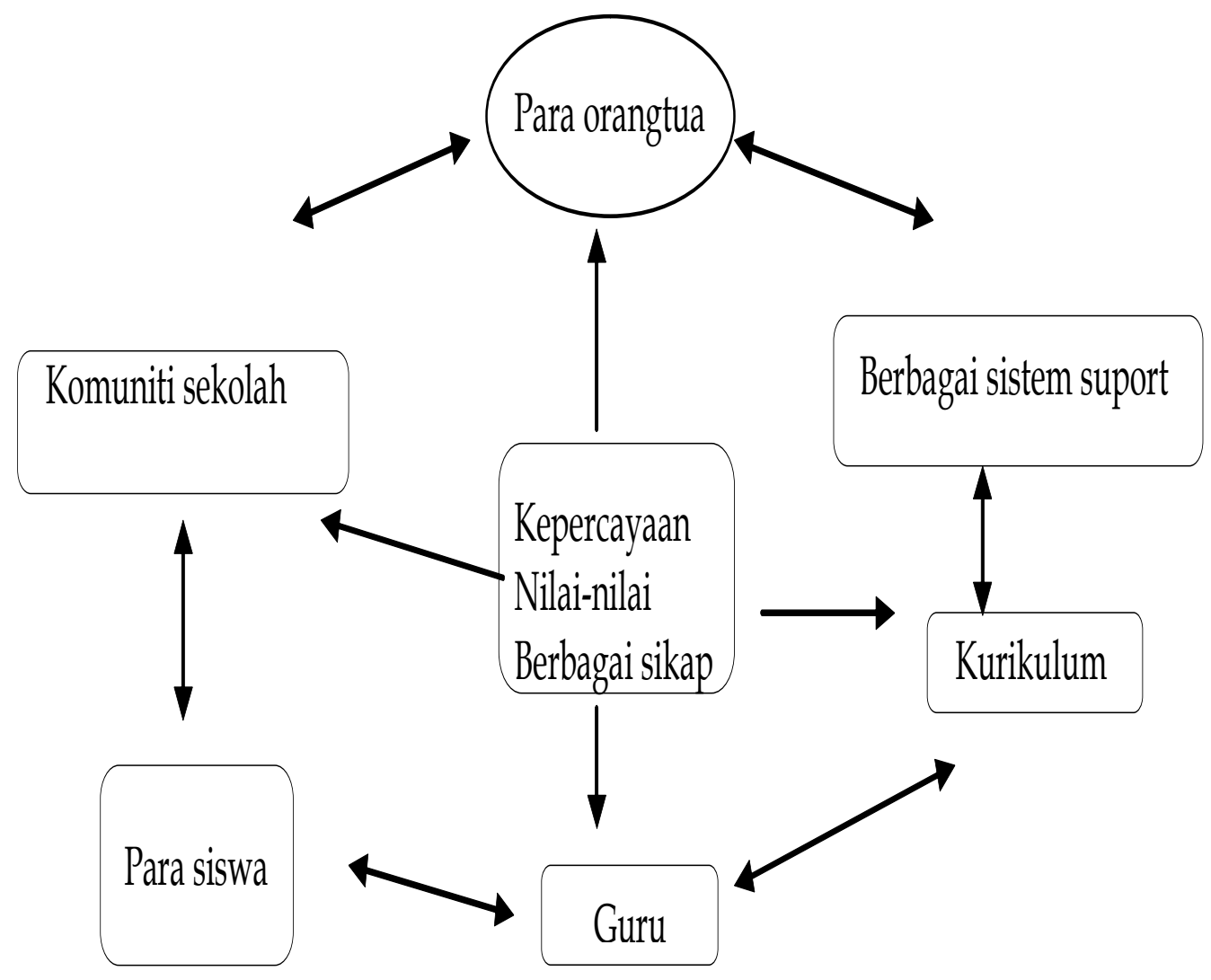

Gambar 1. Pembangunan atmosfir inklusif

Kesuksesan dari pendidikan inklusif berdasarkan kerangka di atas adalah berdasarkan keterkaitan antara kepercayaan, nilai-nilai, dan sikap-sikap dari semua elemen, yaitu para orang tua, para guru, sistemsistem yang mendukung, kurikulum, para siswa, dan komunitas sekolah. Kesemuanya merupakan suatu ikatan yang kuat untuk membangun kesuksesan dari layanan ini.

Adapun core dari inklusi meliputi kepercayaan, nilai-nilai, sikap, guru, siswa, pembelajaran, bantuan dari orang, dan bantuan dari luar. Hal tersebut dapat dilihat pada gambar di bawah ini. 


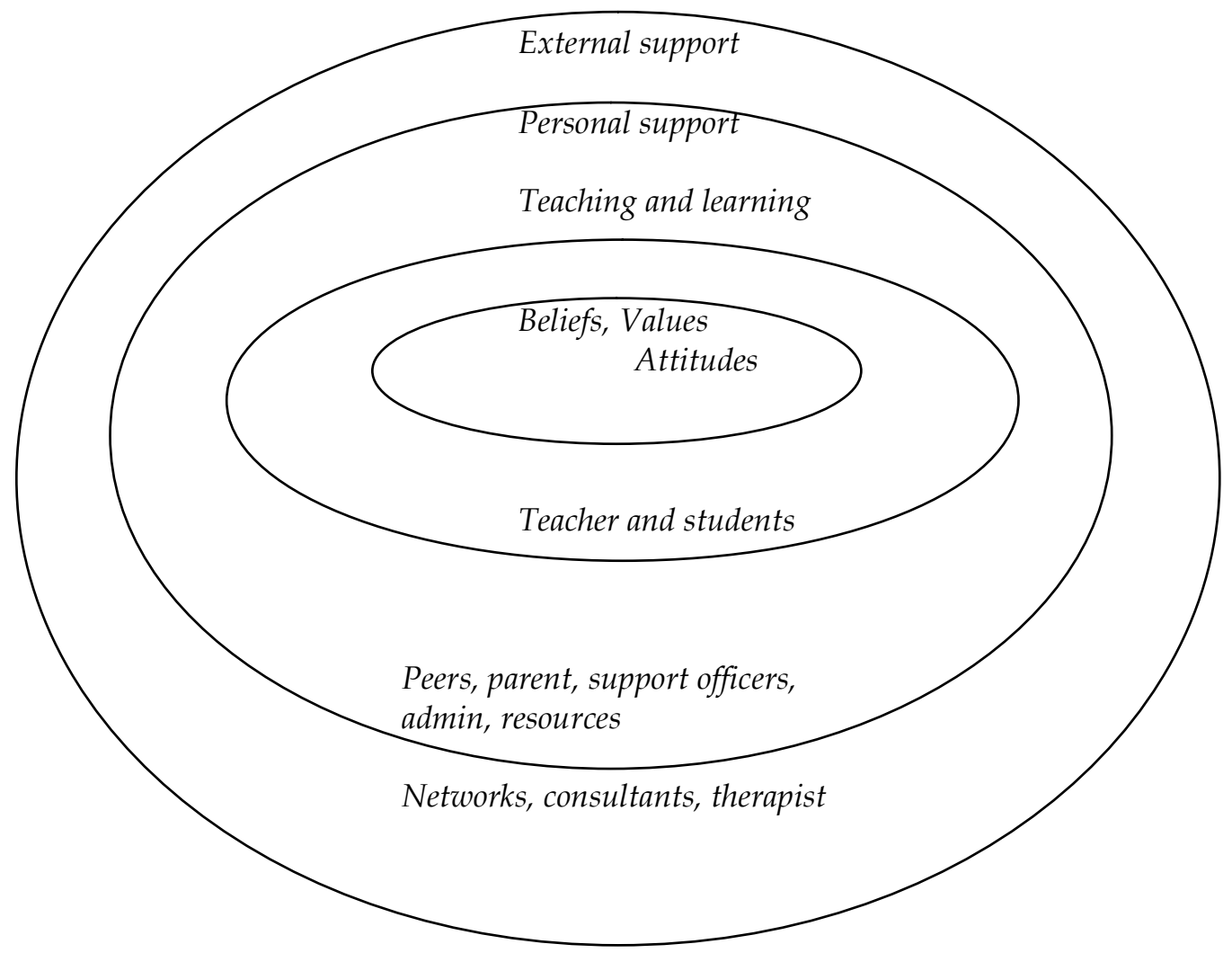

Gambar 2. Elemen inklusi

Bagan di atas menunjukkan bahwa elemen utama dari kesuksesan proses inklusi adalah pada guru. Dalam bagan ini anak-anak dengan kebutuhan khusus berada di lingkungan yang sama dengan anakanak lain dan guru. Di sini anak-anak mendapatkan kesempatan belajar yang sama.

Keunggulan dan berbagai pertimbangan dalam pelaksanaan pendidikan inklusif harus dicermati apabila pendidikan inklusif akan dilaksanakan di Indonesia. Keunggulan dalam penerapan di satu negara mungkin tidak menjadi unggul di negara lain karena faktor seperti budaya dan tingkat pendidikan dari suatu negara.

\section{METODOLOGI PENELITIAN}

Penelitian ini bertujuan untuk memperoleh informasi tentang sikap para mahasiswa Jurusan PLB FIP UNJ terhadap perkembangan keterampilan sosial anak tunagrahita melalui pendidikan inklusif. Variabel penelitian ini hanya ada satu sikap mahasiswa Jurusan PLB FIP UNJ. Penelitian ini dilakukan pada semester pertama tahun ajaran 2007-2008.

Definisi konseptual sikap mahasiswa adalah suatu kecenderungan untuk beraksi secara lisan atau perilaku hasil dari evaluasi terhadap suatu objek melalui panca indra yang dinyatakan dalam bentuk suka atau tidak suka, setuju atau tidak setuju, positif atau negatif, dan nikmat atau tidak nikmat. Definisi operasional sikap mahasiswa adalah skor mengenai kecenderungan untuk beraksi terhadap keterampilan sosialisasi anak tunagrahita melalui pendidikan inklusif yang mencakup aspek: (1) bergaul, (2) komunikasi, dan (3) kerja sama.

Penelitian ini dilakukan di Jurusan PLB FIP-UNJ, dilakukan pada semester kedua tahun ajaran 20062007. Dalam penelitian ini digunakan instrumen berupa angket tertutup dengan skala likert untuk para mahasiswa Jurusan PLB FIP UNJ yang terdiri dari sangat setuju, setuju, ragu-ragu, tidak setuju, dan sangat tidak setuju. Penilaian dalam skala ini adalah sangat setuju $=5$, setuju $=4$, ragu-ragu $=3$, tidak setuju $=2$ dan sangat tidak setuju=1 untuk pernyataan positif. Untuk pernyataan negatif adalah sebaliknya, yaitu sangat setuju $=1$, setuju-2, ragu-ragu $=3$, tidak setuju $=2$ dan sangat tidak setuju=1. Skala tersebut disusun berdasarkan tiga komponen dari aspek, yaitu kognitif, afektif, dan konasi atau perilaku. Komponen objek sikap adalah aspek sosialisasi yang terdiri dari bergaul, komunikasi, dan bekerja sama.

Populasi penelitian ini adalah para mahasiswa Jurusan PLB FIP UNJ. Sampel penelitian sejumlah 30 orang. Pemilihan sampel dilakukan dengan purposive sampling. Dalam penyusunan instrumen ini digunakan validitas bangun pengertian. Untuk perhitungan menggunakan rumus Product Moment. 


$$
r_{x y}=\frac{N(a ̊ x y)-(a ̊ x)(a ̊ y)}{"\left\{N . a ̊ X^{2}-(a ̊ x)^{2}\right\}\left\{N . a_{y^{2}}-(a ̊ Y)^{2}\right\}}
$$

Keterangan:

$\mathrm{r}_{\mathrm{xy}} \quad$ : Angka indeks " $\mathrm{r}$ " product moment

$\mathrm{N} \quad$ : Jumlah sampel

åxy : Jumlah hasil perkalian antara skor $\mathrm{x}$ dan $\mathrm{y}$

åx : Jumlah seluruh skor $x$

åy : Jumlah seluruh skory

r table pada $a=0,05$ adalah 0,63 . Untuk mengetahui realibilitas instrumen ini, penelitian ini menggunakan rumus Alpha Crombach dan hasilnya adalah 0,96 .

Data yang terkumpul selanjutnya dianalisis dengan menggunakan rumus flanagan.

\section{HASIL PENELITIAN}

Dari hasil perhitungan didapat skor keseluruhan terbesar adalah 123 dan skor keseluruhan terkecil adalah 94. Skor rata-rata adalah 105,16. Penelitian ini untuk melihat penyebaran skor dengan menggunakan rumus flanagan, yaitu skor batas positif adalah $27 \%$ dari batas atas 8,1. Skor-skor itu adalah $113,114,115,115,117,117,118$, dan 123 . Skor batas negatif adalah $27 \%$ dari batas bawah 8,1 . Skor-skor itu adalah 89, 94, 94, 96, 97, 97,9 7, dan 97. Skor ratarata sikap positif adalah 116,5 dan skor rata-rata sikap negatif adalah 95,12. Skor mahasiswa yang bersikap tidak positif dan tidak negatif adalah 104,64. Skor urutan data keseluruhan dapat dilihat pada tabel $1 \mathrm{di}$ bawah ini.

Tabel 1. Skor Urutan Data Keseluruhan

\begin{tabular}{|c|c|}
\hline Responden & Skor Perolehan \\
\hline 1 & 123 \\
\hline 2 & 118 \\
\hline 3 & 117 \\
\hline 4 & 117 \\
\hline 5 & 115 \\
\hline 6 & 115 \\
\hline 7 & 114 \\
\hline 8 & 113 \\
\hline 9 & 110 \\
\hline 10 & 110 \\
\hline 11 & 109 \\
\hline 12 & 108 \\
\hline 13 & 107 \\
\hline 14 & 107 \\
\hline 15 & 105 \\
\hline 16 & 105 \\
\hline
\end{tabular}

\begin{tabular}{|c|c|}
\hline Responden & Skor Perolehan \\
\hline \hline 17 & 102 \\
\hline 18 & 102 \\
\hline 19 & 102 \\
\hline 20 & 101 \\
\hline 21 & 100 \\
\hline 22 & 97 \\
\hline 23 & 97 \\
\hline 24 & 97 \\
\hline 25 & 97 \\
\hline 26 & 96 \\
\hline 27 & 94 \\
\hline 28 & 94 \\
\hline 29 & 94 \\
\hline 30 & 89 \\
\hline
\end{tabular}

Dari tabel di atas menunjukkan bahwa skor terendah adalah 89 dan skor tertinggi 123. Dari 30 sampel terdapat tiga orang yang mendapatkan skor 94, empat orang mendapatkan skor 97, tiga orang mendapatkan skor 102, dua orang mendapatkan skor 105, dua orang mendapatkan skor 107, dua orang mendapatkan skor 110, dua orang mendapatkan skor 115, dan dua orang mendapatkan skor 117.

Penyebaran frekuensi skor dapat dilihat pada tabel 2 di bawah ini.

Tabel 2.Skor Keseluruhan Penyebaran Frekuensi

\begin{tabular}{|c|c|}
\hline Skor & Frekuensi \\
\hline 89 & 3 \\
\hline 94 & 1 \\
\hline 96 & 4 \\
\hline 97 & 1 \\
\hline 100 & 1 \\
\hline 101 & 3 \\
\hline 102 & 2 \\
\hline 105 & 2 \\
\hline 107 & 1 \\
\hline 108 & 1 \\
\hline 109 & 2 \\
\hline 110 & 2 \\
\hline 105 & 2 \\
\hline 107 & 1 \\
\hline 108 & 1 \\
\hline 109 & \\
\hline 110 & 1 \\
\hline & \\
\hline
\end{tabular}


Hasil penelitian juga dapat dilihat pada gambar 2 di bawah ini.
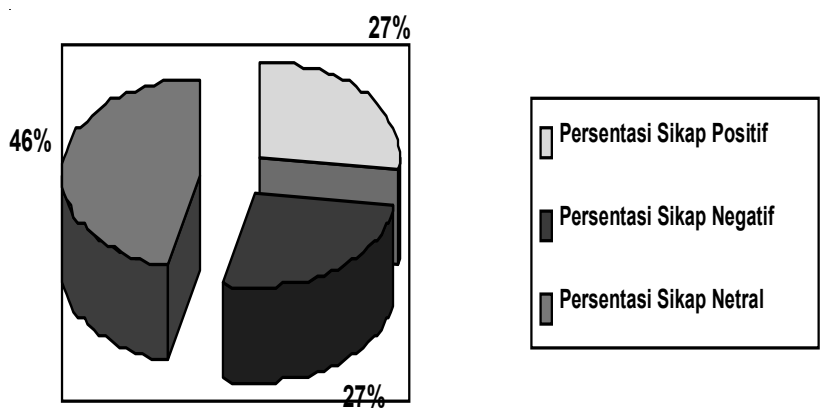

Gambar 2. Skor keseluruhan penyebaran frekuensi

Dari gambar di atas terlihat bahwa belahan sikap yang netral lebih kecil, yaitu $46 \%$ dibandingkan dengan belahan perpaduan antara sikap positif dan negatif. Dalam penelitian ini skor yang diambil adalah skor keseluruhan. Hasil penelitian juga menunjukkan skor rata-rata adalah 105,16. Ini berarti bahwa ratarata sikap mahasiswa Jurusan PLB FIP UNJ berada di antara sikap positif dan negatif karena skor batas bawah adalah dari 89 ke 105, dan skor batas atas adalah 113 ke 123 .

Berdasarkan kajian kepustakaan, sikap terdiri dari tiga aspek, yaitu kognitif, afektif, dan konasi yang sebenarnya tidak dapat dipisahkan sehingga ketika seseorang bersikap maka sikap seseorang tersebut terdiri dari unsur kognitif, afektif, dan konasi. Sikap dinyatakan sesuatu yang berhubungan dengan kecenderungan untuk berpikir, merasa, dan bertindak. Pernyataan dari sikap adalah setuju atau tidak setuju, suka atau tidak suka, pro atau anti, dan nikmat atau tidak nikmat.

Sikap adalah dipelajari dari hasil interaksi terhadap sesuatu. Akibat dari interaksi tersebut maka terbentuklah sikap positif, negatif, dan di antara positif dan negatif. Demikian pula dengan sikap mahasiswa Jurusan PLB FIP UNJ dapat berupa sikap positif, negatif, dan di antaranya atau "abu-abu".

Secara teoretis keterampilan sosialisasi pada anak tunagrahita mengalami beberapa hambatan dan hambatan itu harus dieliminasi agar mereka dapat berfungsi sebagai anggota masyarakat kelak. Sekolah reguler yang menerapkan pendidikan inklusif menyediakan suatu lingkungan yang disengaja untuk anak-anak tunagrahita mengadakan interaksi dengan anak-anak lain baik yang tidak berkebutuhan khusus maupun dengan yang normal.

Pendidikan inklusif secara teoretis dan praktik menyediakan fasilitas agar anak tunagrahita dapat berimitasi dan beridentifikasi dengan anak normal. Akibat dari hubungan simbiosis tersebut anak-anak tunagrahita mendapatkan pengetahuan, pemahaman, dan menerapkan cara-cara bersosialisasi paling tidak mereka dapat bergaul, berkomunikasi, dan bekerja sama sehingga mereka dapat diterima minimal sebagai anggota masyarakat di sekolah tersebut.

Tujuan dari penelitian ini adalah untuk melihat sikap mahasiswa Jurusan PLB FIP UNJ terhadap peningkatan keterampilan sosialisasi yang dibatasi hanya pada aspek bergaul, komunikasi, dan kerja sama dari anak tunagrahita melalui pendidikan inklusif. Sebagai mahasiswa Jurusan PLB yang telah mempelajari baik secara teoretis maupun observasi lapangan, mereka mendapatkan gambaran dan pengalaman langsung dari pelaksanaan pendidikan inklusif. Hasil dari penelitian ternyata mahasiswa masih bersikap antara positif dan negatif terhadap peningkatan sosialisasi anak tunagrahita.

Hasil penelitian menunjukkan bahwa sikap mahasiswa berada di antara sikap positif dan negatif atau dapat dinyatakan dengan sikap abu-abu. Berdasarkan hal ini maka dapat dinyatakan bahwa rata-rata mahasiswa Jurusan PLB FIP UNJ masih memiliki sikap keraguan terhadap keterampilan sosialisasi pada anak tunagrahita melalui pendidikan inklusif.

Hasil penelitian menemukan bahwa skor ratarata keseluruhan dari aspek bergaul adalah 107,75. Untuk skor rata-rata keseluruhan dari aspek komunikasi adalah 112,18. Skor rata-rata keseluruhan dari aspek kerja sama adalah 106,7. Selanjutnya di dapat bahwa skor rata-rata dari sikap positif pada mahasiswa terhadap aspek bergaul adalah 122,66 dan skor rata-rata dari sikap negatif adalah 93,66 . Skor ratarata keseluruhan dari sikap mahasiswa yang abu-abu adalah 107,33.

Penelitian juga menemukan bahwa skor ratarata sikap positif aspek komunikasi adalah 121, skor rata-rata sikap negatif aspek komunikasi adalah 103,66 dan skor rata-rata sikap abu-abu adalah 107,33. Data penelitian juga menunjukkan bahwa skor ratarata sikap positif aspek kerja sama adalah 113, skor rata-rata sikap negatif adalah 97,5 dan skor rata-rata sikap abu-abu adalah 103,5.

Sikap para mahasiswa Jurusan PLB FIP UNJ terbentuk dari lingkungan rumah dan masyarakat tempat mereka berinteraksi. Dalam kaitannya dengan sikap mereka terhadap peningkatan keterampilan sosial yang berupa sikap positif dan negatif serta di antaranya adalah hasil dari interaksi dengan lingkungan berdasarkan observasi terhadap keberadaan, kajian teoretis, dan pengalaman mereka terhadap anak tunagrahita dan pelaksanaan pendidikan inklusif di sekolah-sekolah reguler yang menyelenggarakan pendidikan inklusif. 
Sikap positif mahasiswa memiliki arti bahwa keterampilan sosialisasi anak tunagrahita meningkat karena pendidikan inklusif. Hal ini berarti bahwa pendidikan inklusif memiliki dampak untuk keberhasilan keterampilan sosial anak tunagrahita.

Sebaliknya mahasiswa yang memiliki sikap negatif berarti tidak setuju bahwa peningkatan keterampilan sosialisasi anak tunagrahita dikarenakan pendidikan inklusif. Kemungkinan karena mereka juga mengkaji dan mengobservasi serta memiliki pengalaman yang tidak mendukung bahwa pendidikan inklusif dapat meningkatkan keterampilan sosialisasi. Selanjutnya dosen yang memiliki sikap antara positif dan negatif berarti memiliki sikap "abuabu" atau antara setuju dan tidak setuju atau bahkan ragu-ragu terhadap peningkatan keterampilan sosialisasi anak tunagrahita dikarenakan pendidikan inklusif. Dengan demikian, mahasiswa tidak yakin apakah karena pendidikan inklusif atau karena alternatif faktor lain yang mereka lihat berdasarkan observasi dan pengalaman langsung dan kajian teoretis yang mereka pelajari.

\section{KESIMPULAN}

\section{Kesimpulan}

Berdasarkan hasil penelitian dapat disimpulkan bahwa skor rata-rata sikap mahasiswa Jurusan PLB FIP UNJ adalah 105,16. Mahasiswa yang memiliki sikap positif terhadap peningkatan keterampilan sosialisasi melalui pendidikan inklusif memiliki skor rata-rata 116,5. Mahasiswa yang memiliki sikap negatif terhadap peningkatan keterampilan sosialisasi melalui pendidikan inklusif adalah 95,12. Skor mahasiswa yang bersikap tidak positif dan tidak negatif terhadap peningkatan keterampilan sosialisasi anak tunagrahita melalui pendidikan inklusif adalah 104,64. Ini menunjukkan bahwa adanya keragaman sikap dikalangan mahasiswa Jurusan PLB FIP UNJ meskipun mereka telah mengkaji secara teoretis dan praktik tentang tunagrahita dan pendidikan inklusif.

Dilihat dari skor rata-rata per aspek yang diteliti didapat bahwa skor rata-rata keseluruhan dari aspek bergaul adalah 107,75 dengan rincian bahwa skor ratarata sikap positif mahasiswa adalah 122,66 , skor ratarata dari sikap negatif adalah 93,66 dan skor rata-rata keseluruhan dari sikap mahasiswa yang abu-abu adalah 107,33.

Pada aspek komunikasi penelitian menemukan bahwa skor rata-rata skor rata-rata keseluruhan dari aspek komunikasi adalah 112,18 , skor rata-rata sikap positif aspek komunikasi adalah 121, skor rata-rata sikap negatif aspek komunikasi adalah 103,66, dan skor rata-rata sikap abu-abu adalah 107,33.

Skor rata-rata keseluruhan dari aspek kerja sama adalah 106,7. Data penelitian juga menunjukkan bahwa skor rata-rata sikap positif aspek kerja sama adalah 113, skor rata-rata sikap negatif adalah 97,5 dan skor rata-rata sikap abu-abu adalah 103,5.

Namun tidak disangkal bahwa keberagaman sikap mahasiswa dapat terbentuk akibat berbagai aspek lain, yaitu adanya kontak sosial dengan lingkungan mereka berada, seperti keluarga dan masyarakat. Hal inilah yang menjadikan penemuan yang harus dilakukan tindak lanjut.

\section{Implikasi}

Berdasarkan hasil penemuan bahwa sikap mahasiswa Jurusan PLB-FIP UNJ beragam, yaitu terdapat sikap positif, sikap negatif, dan sikap raguragu terhadap peningkatan keterampilan sosialisasi pada anak tunagrahita melalui pendidikan inklusif sedangkan banyak penelitian yang cenderung menghasilkan kesuksesan dari pendidikan inklusif maka implikasi dari penelitian ini adalah perlu kaji ulang tentang konsep dan pelaksanaan pendidikan inklusif dan variasi dari sikap mahasiswa.

\section{Saran}

Berdasarkan implikasi maka diajukan beberapa saran yaitu sebagai berikut.

1. Jurusan PLB FIP UNJ

a Agar materi pendidikan inklusif tetap diberikan tidak hanya sebagai pengetahuan di kelas tetapi sebagai suatu materi yang terus menerus dikaji dan diteliti melalui pembelajaran yang menyenangkan.

b Dalam memberikan materi tentang pendidikan inklusif dan tunagrahita sebaiknya pembagian teori, praktik, dan lapangan seimbang sehingga mahasiswa mendapatkan pengalaman langsung.

c Perbandingan berbagai alternatif pendidikan untuk anak tunagrahita perlu dikaji dan diteliti sehingga mendapatkan banyak penelitian yang akan mendukung pendidikan yang sesuai bagi anak tunagrahita.

2. Peneliti selanjutnya

Disarankan mengadakan penelitian lanjutan tentang sikap orang tua siswa sekolah dasar terhadap keberadaan siswa tunagrahita di sekolah reguler. Hal ini sangat penting apalagi pemerintah telah mencanangkan persamaan hak, termasuk dalam belajar di sekolah yang sama.

Perspektif Ilmu Pendidikan - Vol. 17 Th. IX April 2008 


\section{DAFTAR PUSTAKA}

Anastasi, A. \& Urbina, S. (1997). Psychology testing. $7^{\text {th }}$ ed. USA: Prentice-Hall Inc.

Andrew, J., Lupart, J., Bachor, D., Crealock, C., Marling, C.D., Marini, A, and Piper, D. (1993). The inclusive classroom, educating exceptional children. Canada: Nelson.

Ashman, A. (1994). Students with an intellectual disability. Dalam A.Ashman. dan J. Elkins (Ed). Educating Children with Special Needs. $2^{\text {nd }}$ ed. Australia: Prentice Hall

Ashman, A., \& Elkins, J. (1994). Providing learning opportunities for all children. Dalam A. Ashman, dan J.Elkins. (Ed.). Educating children with special needs. Australia: Prentice Hall.

Azwar, S. (1995). Sikap manusia, teori dan pengukurannya. Edisi ke 2. Yogyakarta: Pustaka Pelajar Offest.

Cartwright, P.G, Cartwright, A.C \& Ward, E.M. (1989). Educating special learners. USA: Waasworth Inc.

Chaplin, C.P. (1993). Kamus lengkap psikologi. Jakarta: Raja Grafindo Persada.

Drew, C.J., Logan. D.R., \& Hardman, M.L (1990). Mental retardation. A life cycle approach. $4^{\text {th }}$ ed. New York: Macmillan Publishing Company.

Grossman, H.J. (1983). Classification in mental retardation. Washington: American Association On Mental Deficiency.

Grusec. (1985). Dalam John E. Richters dan Everett Watters, Atachment and Sociallization The Positive Side of Social Influence. http:www.psycology.sunysb.ed/attachmen/ online/richters_waters.pdf
Hallahan, D.P., \& Kauffman, J.M. (1986). Exceptional children. Introduction to special education. New Jersey: Prentice Hall.

Henslin. (1999). Socialization.Wikipedia, the free encyclopedia (http://enwikipedia.org/wiki/ Social_Psychology.\%28Psychology \% 29\#Principles_of_Social_Psychology)

Lang, G., \& Berberich, C. (1995). All children are special. Creating an inclusive classroom. Australia: Eleanor Curtain Publishing.

Mitchell, D. (1994). Inclusive education in Asia: Policies, problems and possiblities. Hamilton: University of Waikato, School of Education.

Morgan , C.T., dkk. (1986). Introduction to psychology. ( $7^{\text {th }}$ ed.). New York: McGraw-Hill Book Company Mueller, D.J. (1986). Measuring social attitudes: A handbook for researchers and practitioners. New York: Teacher College, Columbia University.

Papalia, D.E \& Wendkos, S. (1985). Psychology. Olass: McGrow-Hill Back Company.

The Collins, Paperback English Dictionary. (1991). Great Britain: HaperCollins Manufacturing.

Wortmand, C.B., Loftus. E.F., \& Knopf.A.A., (1985). Psychology. $2^{\text {nd }}$ ed. New York.

Weiten, Lloyd, W., \& Margareth, A. (1994). Psychology applied to modern life. $4^{\text {th }}$ ed. New York: Wadsworth Publishing

\section{KETERANGAN PENULIS}

Siti Nuraini, dilahirkan September 1961. Pendidikan terakhirnya adalah Master of Special Education the University of Wakaito, New Zealand. 